\title{
Litígio Árabe-israelense: A Importância da ONU para a Solução do Conflito no Oriente Médio
}

Noeli Rodrigues ${ }^{1}$

\section{RESUMO}

O tema abordado é a atuação da Organização das Nações Unidas, pois se entende que a intervenção da Organização torna-se fundamental para a solução do conflito milenar no Oriente Médio. Nesse sentido, o reconhecimento da Palestina seria o meio de resolver o litígio.

Palavras-chave: Organização das Nações Unidas. Conflito árabe-israelense. Solução de Conflitos.

O presente boletim discute a importância da atuação da Organização das Nações Unidas para a solução de conflitos internacionais. 0 objetivo central é verificar a importância da ONU para a solução do conflito árabe-israelense, que se estagnou devido à interferência, por assim dizer, de outros atores internacionais. Analisa-se o comportamento desses atores devido a sua abrangência e influência, principalmente a partir da década de 1970, nas Relações Internacionais.

Entende-se que a influência da ação de atores internacionais no contexto de interdependência propicia, segundo BEDIN (2001), maiores possibilidades de intercâmbio e fluxos internacionais, promovendo, desse modo, o aprofundamento de assimetrias entre países. Esses fatores tornam as relações internacionais complexas e, atribuem-lhes, riscos. Nesse contexto, de novas possibilidades políticas e sociais, ocorreu o crescimento não apenas dos Estados, mas das Organizações Internacionais. Com as transformações decorrentes dos novos atores emergem novos jogos, regras e novas estratégias para a manutenção no Sistema Internacional (BEDIN, 2001).

\footnotetext{
${ }^{1}$ Mestranda em Ciência Política pela Universidade Federal do Paraná (UFPR), graduada em Relações Internacionais pelo Centro Universitário Internacional UNINTER. e-mail: noeli82ri@gmail.com
} 
As estratégias para manter-se no SI são evidenciadas em casos particulares nas relações internacionais. Esses casos envolvem as OIs, principalmente a ONU, e conflitos ocorridos na segunda metade do século XX.

Como exemplo, o desenvolvimento da operação de paz liderada pela Organização das Nações Unidas durante a crise no Canal de Suez (1956) - Grã-Bretanha e França, acionistas e beneficiárias do Canal ficam do lado de Israel, ou mesmo seu posicionamento em relação ao conflito árabe-israelense, no que se refere à Resolução 242, aprovada pelo Conselho de Segurança das Nações Unidas. Como descreve NYE (2009), as "superpotências" pressionaram tanto árabes quanto judeus a aceitarem um cessar-fogo, porém, as determinações feitas por meio da Resolução 242 do CS não ficaram claras, pois esta podia ser interpretada de diversas formas, de acordo com o idioma. Essa situação de ambiguidade causada por uma determinação da ONU não resolveu o problema, pelo contrário, acirrou ainda mais a animosidade entre esses povos (NYE, 2009).

Como observa SATO (2003), a avaliação de cada ator é feita de maneira diferente, pois cada situação tem um significado específico. Uma disputa comercial ou territorial; um acordo de cooperação; um conflito armado real ou em potencial, são situações que se transformam em ações políticas. Como as consequências políticas resultantes da crise do Canal de Suez, no qual a União Soviética (URSS) passou a influenciar o conflito no Oriente Médio, e na aproximação da relação entre Estados Unidos e Israel, a partir da década de 1960 (LAMAS, 2004).

No que se refere à intervenção de atores internacionais, ou seja, Estados e Organizações Internacionais, NYE (2009) destaca o contexto da aprovação da Resolução 242 das Nações Unidas, que pôs fim à guerra entre árabes e israelenses em 1967. No decorrer dos anos, o propósito da determinação, assim como o da Resolução 181(1947), não foi respeitada.

Todos esses aspectos, aliados a políticas radicais praticadas por israelenses ou palestinos, são grandes obstáculos para a paz. Por esse motivo AUDI (2010) revela a importância da Organização das Nações Unidas: 
O papel da ONU terá sempre que ser fundamental e não imprudente, (...). Para alguns observadores, Israel luta por uma terra que sempre foi deles. Os palestinos, por sua parte, defendem o "utis possidetis" - "como possuis, assim possuais" do direito romano, reconhecido pelo direito internacional (AUDI, 2010, p.56).

Embora haja argumentos relevantes para ambos os lados e resguardados pelo Direito Internacional, o debate apresentado não busca resolver as questões relacionadas ao Fundamentalismo Religioso que dá combustão a uma espécie de "novas guerras", que são frequentes na região do Oriente Médio. Para AUDI (2010), essa região é uma das mais conflituosas da agenda internacional, com litígios complicados e confusos que, há décadas, abalam o mundo.

Não cabe, portanto, tomar partido de nenhum dos lados envolvidos, apenas analisar, de acordo com a história, os argumentos expostos tanto por palestinos quanto por israelenses, e definir o que, de fato, impede a solução do litígio que confere ao Oriente Médio um ambiente essencialmente instável. Essa questão se mostra relevante para compreensão do conflito entre árabes e judeus, pois representa a faceta que emperra a solução do litígio. Coloca-se como pressuposto que o reconhecimento da Palestina seria a condição fundamental para a solução deste conflito milenar.

\section{Referências bibliográficas}

AUDI, Maria Tereza De Oliveira. Caminho para a paz: conflito palestino-israelense. Revista Juris da Faculdade de Direito, Fundação Armando Alvares Penteado. Volume 3 - Jan. a Jun./2010. São Paulo: FAAP, 2010.

BEDIN, Gilmar Antônio. A Sociedade Internacional e o Século XXI: Em Busca De Uma Ordem Mundial Justa e Solidária. Rio Grande do Sul: Unijuí, 2001.

LAMAS, Bárbara Gomes. Palestina e Israel: Acordos de Oslo, Camp David II e o Mapa da Paz. Conjuntura Internacional - Cenários PUC Minas, Minas Gerais, nov. 2004.

NYE, Joseph Jr. Cooperação e Conflito nas Relações Internacionais. São Paulo: Editora Gente, 2009. 
SATO, Eiiti. Conflito e Cooperação nas Relações Internacionais: as Organizações Internacionais no Século XXI. Revista Brasileira de Política Internacional. Vol. 46, n. 2 -. Brasília, jul./dez. 2003. 